\title{
A NEW AMERICAN AMBLYOPONE, WITH NOTES ON THE GENUS (HYMENOPTERA: FORMICID $\nexists)^{1}$
}

\author{
By William L. Brown, Jr. \\ Biological Laboratories, Harvard University
}

Amblyopone (Stigmatomma) trigonignatha new species

Figure 1

Holotype worker: Total length measured from lateral profile, mandibles included but sting excluded, $6.12 \pm .10$ mm.; Weber's length of alitrunk, $1.60 \pm .05 \mathrm{~mm}$.; maximum measurable length of the head from the center of the anterior clypeal border to a line connecting the posterior extremities of the occipital corners, $1.22 \pm .005$ mm.; maximum width of head, $1.05 \pm .005 \mathrm{~mm}$.; cephalic index, $86 \pm 1$; left mandible, straightline distance, when closed, from the point of contact with the anterior border of head to apex, $0.80 \pm .01 \mathrm{~mm}$., or, more roughly, about two thirds of the length of the head proper.

Head a little more slender than in $A$. (S.) pallipes (Haldeman), sides gently convex, greatest width at about the anterior third, slightly convergent behind and passing into the rounded occipital corners through easy curves; posterior border of head moderately but distinctly concave in outline. "Amblyoponine teeth" at the anterolateral corners of the head reduced to small, bluntly rounded tubercles which are more or less hidden in dense pilosity; this reduction much greater than in any small specimens of the pallipes complex I have seen. Clypeus dorsally weakly convex, its anterior apron rather narrow, with a very feebly convex anterior border which appears straight at some angles of view. This apron is rather abruptly terminated on each lateral extremity by an angle which marks the boundary between

1 Published with a grant from the Museum of Comparative Zoology at Harvard College. 
it and the medial wall of a notch which receives the acute, triangular basal mandibular tooth. Anterior margin of clypeal apron set with twelve small, regular separated denticles which are truncate, subcylindrical and not socketted on subconical tubercles as are those of pallipes and its subspecies, also one of these tubercles on each short lateral margin. This makes 14 denticles in all, more than in pallipes, all separate, smaller and more regular than in the pallipes complex, and with the exception of the tooth on each lateral margin, on approximately the same level. Eyes about the same size and in the same

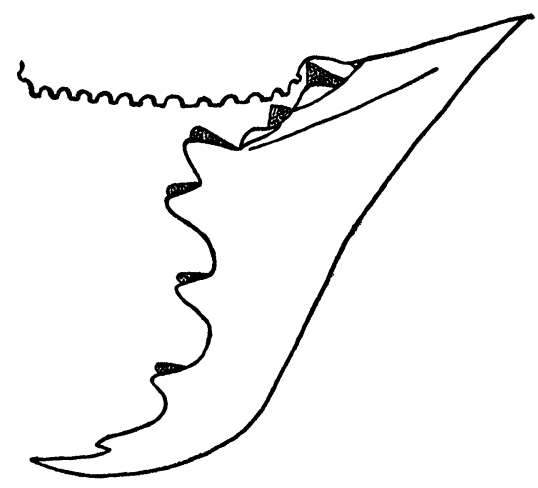

Figure 1. Amblyopone (Stigmatomma) trigonignatha new species, worker, left mandible and anterior clypeal border.

position as in medium-sized pallipes workers, with only 3 or 4 of the facets actually pigmented in each. A faint median depression on the cephalic dorsum at about the midlength evidently represents a vestige of the anterior ocellus.

Mandibles distinctive; considering only the basal halves each forming an obtuse triangle, with the inner border of the basal part just before the midlength distinctly angulate at somewhat more than a right angle; this angle, which is capped by two massive, blunt double teeth partially fused at their bases, marks off fairly distinct basal and apical borders. The basal border bears two rows of teeth, a dorsal and a ventral; there are two teeth in each row, the ventral ones triangular, 
acute, the dorsal low and rounded and alternating with the ventral ones so that all may be seen from a position directly dorsad. The more basal of the two ventral teeth is the larger, and this fits into the notch mentioned above just lateral to the clypeal apron. The apical border distad of the two large double teeth at the angle with two more blunt, massive double teeth, which are well separated; these followed by a smaller acute tooth just before the acute, stoutly spiniform apex. Seen from the side, the mandibles are nearly twice as thick dorsoventrally as in pallipes, and not quite so strongly projecting anteriorly; the apices somewhat recurved.

The alitrunk is very similar to that of small pallipes workers, but perhaps very slightly more slender; the rounded lamellæ at the base of the propodeal declivity smaller. The petiolar node is very slightly longer than broad seen from above, much as in smaller workers of pallipes.

Sculpture throughout less pronounced than in pallipes, the head and thorax shining to the naked eye. Seen at very high magnifications, the dorsum of the head is sown with very small, regular punctures which are separated from each other by plane, shining surfaces which do not form the fine longitudinal costulation or rugulation seen in the forms of pallipes. Clypeus very indistinctly and irregularly longitudinally striate; mandibles striate longitudinally as in pallipes, but less regularly and distinctly. Sculpture of dorsum of alitrunk much like that of the head, but the sides posteriorly are longitudinally striate as in pallipes; propodeal declivity with a large central area devoid of transverse striæ and smooth and shining.

Color rather uniform medium ferrugineous. Other characters of structure and pilosity within the range of variability shown by small to medium-sized pallipes workers from the eastern United States. Male and female unknown.

Holotype worker, Museum of Comparative Zoology, Harvard University, Catalog No. 28231. Collected at Concord, North Carolina, by Dr. D. L. Wray, who sifted 
it from leaf mold by means of the Berlese funnel. One Stigmatomma pallipes worker was also taken by the same funnel, a fact which has caused me to examine a large quantity of pallipes specimens in making sure that the new species cannot be an extreme example of the very variable common species. I have found it very generally true that closely related ant species often occur in the same Berlese batch, especially with forms living in or beneath the soil cover or in rotten logs, so the proximity of the two forms in collecting need not trouble us too much. The differences are so striking that I cannot consider trigonignatha as merely an abnormal specimen of pallipes, and the sting rules out the possibility of it being an ergatoid male like those found in Ponera.

\section{Amblyopone (Stigmatomma) pallipes (Haldeman)}

Typhlopone pallipes Haldeman, 1844, Proc. Acad. Nat. Sci. Phila., 2: 54, worker.

Stigmatomma pallipes subsp. montigena Creighton, 1940, Amer. Mus. Novit., No. 1079, p. 7, figs. 6 and 8.

The remainder of the synonymy is given in.Creighton's paper cited above on page 3. The correct spelling of Provancher's name is Arotropus binodosus, not "Atropus binodus,'” as Creighton has it.

Since Dr. Creighton's paper describing the form montigena was published, I have been accumulating Stigmatomma specimens year by year from various states, principally Pennsylvania, North Carolina and Tennessee. I have looked over specimens from the Pennsylvania Alleghenies (where Stigmatomma is often the most abundant or only ant occurring in very wet mountain valleys in which rhododendron and hemlock form the main cover) with the hope of finding montigena specimens. I succeeded in finding some specimens with a rather convex anterior clypeal border, but these were often mixed in the same colony with specimens having the border nearly straight. Two specimens from rich, low beech woods in a city park in Philadelphia, however, showed very marked convexity of the clypeal border to a degree comparable with the montigena types; since these latter 
specimens were taken in very close association with several other workers having much less convex borders, I believe that the geographical basis of this subspecies becomes very weak. The length of the funicular joints, the sculpture, and the presence or absence of a tubercle distad of the basal tooth are also variable characters in both Pennsylvania and North Carolina specimens, and the first of these auxiliary characters is subject to differences brought about by the contraction of funicular joints into one another to different degrees at death in alcohol. In conclusion, Dr. Creighton's material, while reasonably abundant, just happened to show a distributional pattern which led naturally to the erection of a subspecies. The additional material now available shows so many contradictory features that montigena cannot be retained as a separate form any longer.

\section{Amblyopone (Stigmatomma) subterranea Creighton}

I regard this form for the present as a good species, though it was described as a subspecies of pallipes in Creighton's 1940 paper (p. 8, fig. 4). Though the difference from pallipes is very slight, it seems constant in the specimens from Kansas, and the specimen from Austin, Texas, may also be considered as of this form instead of as a pallipes-subterranea intergrade. Buren has reported this form from Iowa, so the range appears wide in the plains states. Specimens of pallipes from Illinois and western Tennessee do not seem to intergrade with subterranea, and no true intergrades seem yet to have been reported from anywhere, with the exception of the single doubtful specimen from Texas. Though it is true, as Creighton states in his description, that most of the sculpture of subterranea is rather light, the Kansan and Texan specimens show rather characteristically strong longitudinal rugulæ in the area just behind the frontal region of the dorsum of the head which are not quite like those of pallipes. The structure of the anterior clypeal border seems rather distinct and diagnostic also.

Though Creighton regarded the single Arizona record of Stigmatomma as doubtful in 1940, there have been 
several collections made in that state by Mr. R. G. Wesson since Creighton's writing. Dr. Creighton has suggested to me in a letter that these specimens may provide a basis for reviving Wheeler's Arizona race, but since these collections are not presently available to me, I shall provisionally accept the synonymy of this form under $S$. pallipes pallipes.

Subgenera of the genus Amblyopone Erichson

In 1934, Mr. John Clark of Melbourne ${ }^{1}$ adopted Wheeler's earlier suggestion ${ }^{2}$ that Stigmatomma Roger, Fulakora Mann and Xymmer Santschi were only subgenera of Amblyopone Erichson. On the basis of workers alone, it is hard to see why any of these names should be maintained if the known world fauna of the complex is considered as a whole. An examination of the venation of the winged males and females of several species referred at present to Amblyopone (aberrans Wheeler, several forms of the australis-cephalotes complex) and to Stigmatomma (rothneyi Forel, pallipes (Haldeman), pallipes oregonensis Wheeler) reveals a difference which, if consistent in the two groups, will serve to separate them satisfactorily as subgenera; I should not be surprised to find this character intergradient and thus not any longer separatory when more of the males and females are known. In Stigmatomma, the second free abcissa of $R_{\mathrm{s}}\left(\mathrm{R}_{\mathrm{s}} \mathrm{FA} 2\right.$ ), the vein which splits the cubital cell longitudinally, is present in its entirety (somewhat weak in rothneyi), while in all the Amblyopone sensu stricto, this vein is entirely gone and the cubital cell resulting is very large and undivided. Furthermore, the venation of the Stigmatommas from the United States (not rothneyi) is more primitive in that the first free abcissa of M (M FA 1), the posterior part of the vein persistently called the "basal vein," is lined up or nearly lined up with crossvein $\mathrm{cu}-\mathrm{a}$, a condition characteristic of the Myrmeciini and also of at least some Mystrium Roger and Myopopone Roger.

1 Clark, 1934, Mem. Nat. Mus. Victoria, No. 8, p. 27.

2 Wheeler, 1927, Proc. Amer. Acad. Arts \& Sci. 62: p. 1. 
I have not seen any winged forms of Fulakora Mann; this genus or subgenus cannot at present be separated from Stigmatomma, since the prime character, approximation of the frontal carinæ, is intermediate through to S. williamsi Wheeler (Philippines) in at least two Australian forms of Fulakora described by Clark (punctulata, gracilis). Williamsi and silvestrii Wheeler (Japan) form a very close series connecting forms like punctulata with those like denticulata Mayr and other "typical" Stigmatomma. In the absence of evidence to the contrary, I propose that the name Fulakora Mann be considered a synonym of Amblyopone (Stigmatomma).

Two synonyms were unwittingly created by Wheeler (see synonymy below) when he stated that he thought the use of Clark's names, proposed in lit. at an earlier date, to be "inadvisable." Both names were put in print, with genotypes stated. According to present practice as employed by many systematists, these names are available and in force, a fact pointed out to me by my friend, Mr. Floyd G. Werner. It appears best to list them formally as synonyms. The arrangement below shows my conclusions as to the relationships of the names discussed above. For fuller synonymy, references can be found in Emery's section on the Amblyoponini in the Genera Insectorum.

Genus Amblyopone Erichson

Erichson, 1841, Arch. Naturg., 8: 254, 260.

Neoamblyopone Wheeler, 1927, Proc. Amer. Acad. Arts and Sci., 62: 1.

Protamblyopone Wheeler, Idem., p. 1.

As far as I can see, there is only one valid subgenus in addition to Amblyopone (s. str.):

Subgenus Stigmatomma Roger

Roger, 1895, Berlin. Ent. Zeitschr., 3: 250. Stigmatomma (Xymmer) Santschi, 1914, Boll. Lab. Zool. Portici, 8: 311.

Ximmer Emery, 1919, Ant. Soc. Ent. Belg., 59: 106, as subgen. of Stigmatomma. 
Fulakora Mann, 1919, Bull. Mus. Comp. Zool., 63: 279, subgen. of Stigmatomma.

Amblyopone (Xymmer) Clark, 1934, Mem. Nat. Mus., Melbourne, No. 8, p. 27.

A. (Stigmatomma) Clark, 1934, Idem., p. 27.

A. (Fulakora) Clark, 1934, Idem., p. 27 et suiv.

Since both Santschi and Emery have shown (works cited in synonymy) that Santschi's Xymmer muticum is connected to Stigmatomma through $A$. (S.) belli Forel, I can see no reason for retaining Xymmer as a separate subgenus any longer. 

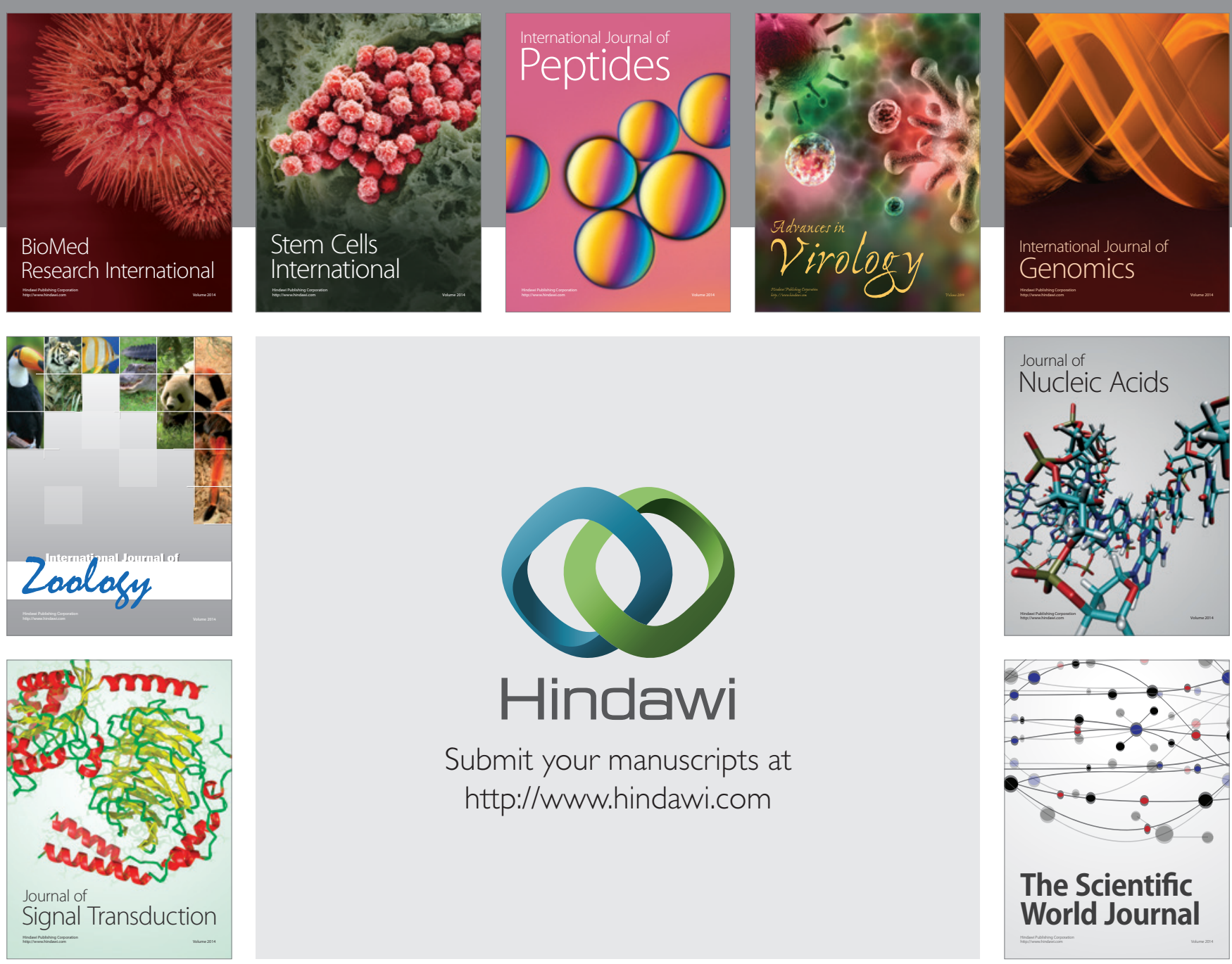

Submit your manuscripts at

http://www.hindawi.com
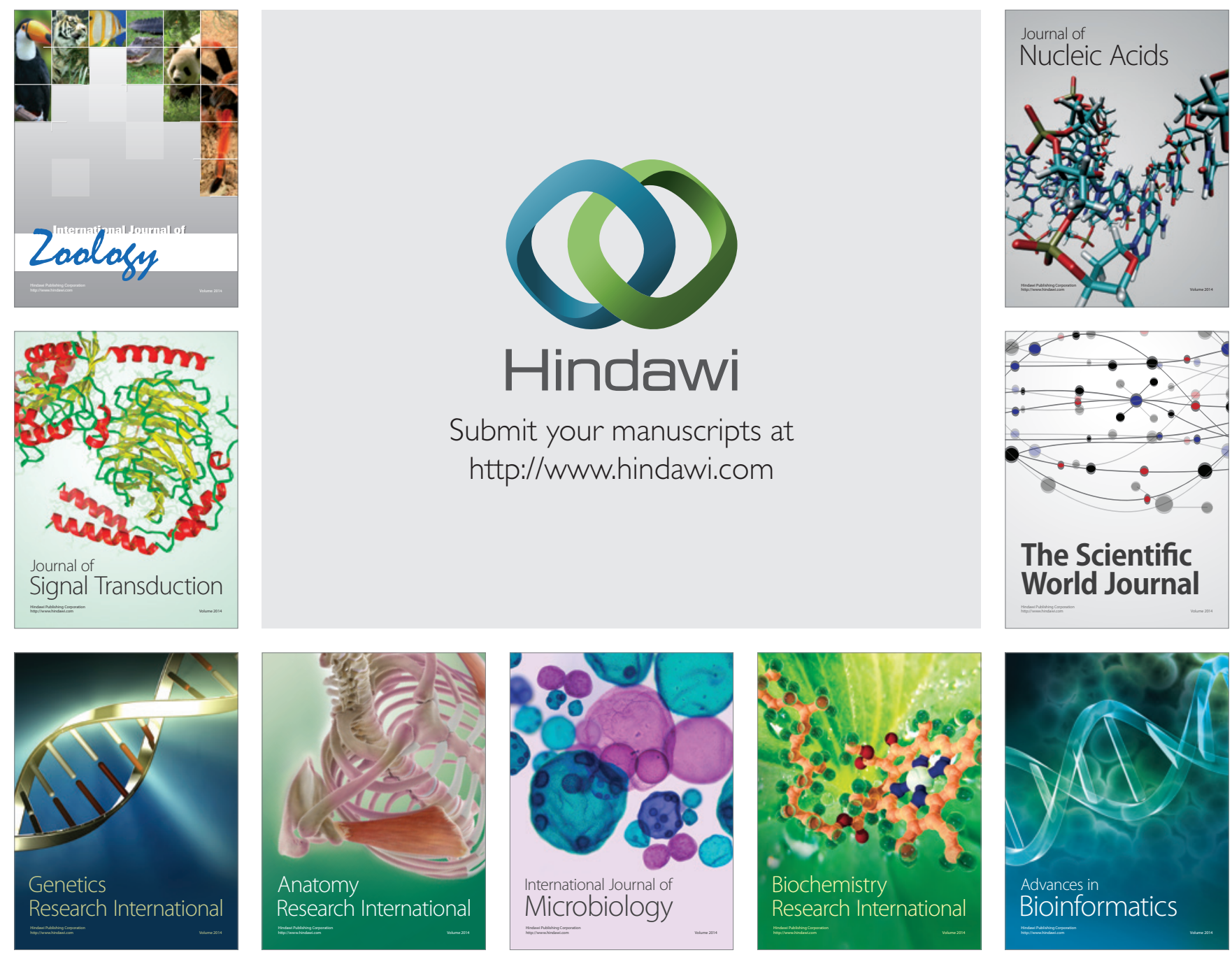

The Scientific World Journal
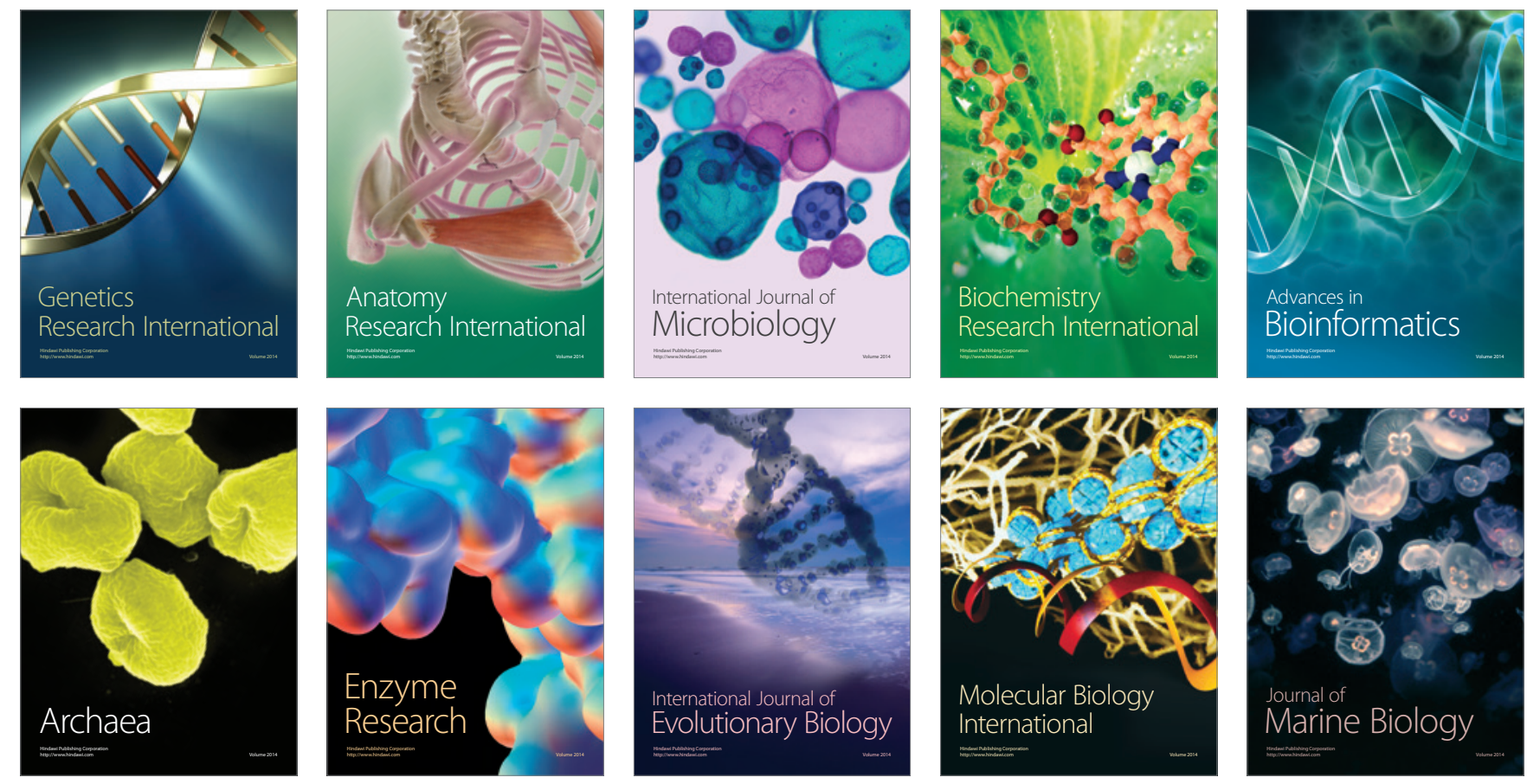